\title{
ANALYSIS OF 111 PATIENTS WITH CERVICAL SPINE FRACTURES IN A TERTIARY HOSPITAL
}

\author{
ANÁLISE DE 111 PACIENTES COM FRATURAS DA COLUNA CERVICAL \\ EM UM HOSPITAL DE ATENDIMENTO TERCIÁRIO
}

\section{ANÁLISIS DE 111 PACIENTES CON FRACTURAS DE COLUMNA CERVICAL EN UN HOSPITAL DE TERCER NIVEL}

Hugo Vilchis Sámano ${ }^{1}$, Edgar Villeggas Esouivel ${ }^{1}$, Luis Muñiz Luna ${ }^{1}$

1. Instituto Mexicano del Seguro Social, Hospital de Ortopedia y Traumatología Lomas Verdes. Unidad Médica de Alta Especialidad, Naucalpan de Juárez, México.

\begin{abstract}
Objective: To describe the epidemiology of 111 patients to determine the age group affected, the level of fracture, fracture classification, and type of treatment. Methods: Descriptive study of 111 cases of cervical spine fracture treated at the Hospital of Traumatology and Orthopedics Lomas Verdes - IMSS from March 2009 to October 2014. Results: The condition appeared in 88\% of men. The age range was 16-81 years, with an average of 40 years. The most common fracture according to the AO classification was type A (57\%). The segments most affected were C5-C6, C6-C7, C6 and C4-C5 (24.32\%, 17.1\%, 9.9\% and 8.1\%). Neurological involvement occurred in 46.8\%. The most common mechanism of injury was high energy. Surgical treatment was performed in $78.4 \%$ of patients, being one-level corpectomy with placement of mesh and plate, and posterior fixation with facet screws the most appropriate procedures (31.5\% and 27.9\%, respectively). Conclusions: Males were the most affected, the highest incidence was in C5-C6 and C6-C7 levels and the surgical procedure was the most used.
\end{abstract}

Keywords: Spine; Spinal fractures; Epidemiology; Descriptive.

RESUMO

Objetivo: Descrever a epidemiologia de 111 pacientes para determinar a faixa etária acometida, o nível da fratura, a classificação e o tipo de tratamento. Método: Estudo descritivo de 111 casos de fratura da coluna cervical tratados no Hospital de Traumatologia e Ortopedia Lomas Verdes - IMSS, de março de 2009 a outubro de 2014. Resultados: A patologia apresentou-se em 88\% dos homens. A faixa etária foi de 16 a 81 anos, com média de 40 anos. A fratura mais frequente de acordo com a classificação AO foi o tipo A (57\%). Os segmentos mais afetados foram C5-C6, C6-C7, C6 e C4-C5 (24,32\%, 17,1\%, 9,9\% e 8,1\%). Verificou-se comprometimento neurológico em 46,8\%. O mecanismo mais comum de lesão foi o de alta energia. O tratamento cirúrgico foi realizado em 78,4\% dos pacientes, sendo a corpectomia de um nível com colocação de malha e placa e a fixação posterior com parafusos facetários os procedimentos mais indicados (31,5\% e 27,9\%, respectivamente). Conclusões: O sexo masculino foi o mais afetado, a maior incidência foi nos níveis C5-C6 e C6-C7 e o procedimento cirúrgico foi o mais utilizado.

Descritores: Coluna vertebral; Fraturas da coluna vertebral; Epidemiologia; Descritiva.

\section{RESUMEN}

Objetivo: Describir la epidemiología de 111 pacientes para determinar el grupo de edad afectado, el nivel de la fractura, su clasificación y tipo de tratamiento. Método: Estudio descriptivo de 111 casos de fractura de columna cervical tratados en el Hospital de Traumatología y Ortopedia Lomas Verdes - IMSS, de marzo de 2009 a octubre de 2014. Resultados: La patología se encontró en el 88\% de los hombres. El rango de edad fue de 16 a 81 años, siendo el promedio 40 años. Las fracturas más frecuentes según la clasificación AO fueron el tipo A (57\%). Los segmentos más afectados fueron C5-C6, C6-C7, C6 y C4-C5 (24,32\%, 17,1\%, 9,9\% y 8,1\%). El compromiso neurológico se presentó en el 46,8\%. El mecanismo de lesión más común fue el de alta energía. El tratamiento quirúrgico se llevó a cabo en 78,4\% de los pacientes, siendo la corpectomía de un nivel más colocación de malla y placa además de la fijación posterior con tornillos facetarios los procedimientos más indicados (31,5\% y 27,9\%, respectivamente). Conclusiones: Los hombres fueron los más afectados, la mayor incidencia fue en los niveles C5-C6 y C6-C7 y el procedimiento quirúrgico fue el más utilizado.

Descriptores: Columna vertebral; Fracturas de la columna vertebral; Epidemiología; Descriptiva.

\section{INTRODUCTION}

Cervical spine fractures are a common pathology in our population, significantly affecting the economically active population in terms of work, social, and family aspects. The incidence in the general population is not known precisely, but there are reports of up to
$64 / 100,000$ people with fractures of all spine segments, ${ }^{1}$ including $12 / 100,000$ people with fractures of the neck. ${ }^{2}$ Spine fractures, besides presenting associated spinal cord injury, are devastating, and an annual incidence of 35-40 cases per million people in Canada and the United Sates, respectively, has been reported. ${ }^{3-5}$ This study describes the epidemiology of 111 patients over a 
5-year period at a tertiary hospital of the Mexican Institute of Social Security, determining the age group most affected, the level of fracture, the classification, and the type of treatment. This analysis will serve as the basis for updating the internal norms and procedures of the spine service, based on the corresponding needs, and for updating of electronic databases, seeking to improve the quality of information available.

\section{METHOD}

A search was conducted from March 2009 to October 2014 on all cases of spine fractures treated in the spine module of the Medical Specialty Unit of Hospital de Traumatología y Ortopedia Lomas Verdes IMSS, obtaining information from the patient medical records. Subsequently, an Excel database was created, which was analyzed using the program SPSS. Approval of the Institutional Review Board was not required for this type of study.

\section{RESULTS}

A total of 564 patients were registered from March 2009 to October 2014, of which $19.68 \%$ (111 patients) had lesions of the cervical spine.

Of this total, $88 \%(98)$ were men and $12 \%$ (13) were women. The age range was from 16 to 81 years, with a mean age of 40 years and a modal value of 22, followed by 21 and 42 years.

Based on the AO classification, type A was predominant, with 57\% (63), followed by type B, with 32\% (36) and type C, with 11\% (12). The most common trauma mechanism was automobile accident, with $38.7 \%$ (43), followed by falling from a height with $30.6 \%$ (34) and thirdly, motorcycle accidents, with 9.9\% (11 patients). (Figure 1) The fractures affected more than one vertebra in $67 \%$ (74), and a single vertebra in 33\% (37).

The segments affected are described in Table 1 and Figure 2; segments C5-C6, with 24.32\% (27 patients) and C6-C7, with 17.1\% (19 patients) were the segments most affected.

The most common neurological impairment, based on the Frankel scale, was Frankel E with 46.8\% (52), followed by Frankel A: 30.6\% (34), Frankel D: $11.7 \%$ (13) and Frankel B: 4.5\% (5). There was neurological improvement in 6.3\% (7) of the patients. (Figure 3 )

Treatment was conservative in $21.6 \%$ (24) and surgical in $78.4 \%$ (87). Of the patients who received surgical treatment, (Figure 4), single-level corpectomy with placement of mesh and plate was the most frequent, with $31.5 \%$ (35), followed by posterior cervical fixation with facet screws, in $27.9 \%$ (31) and finally, posterior cerclage in $4.5 \%$ (5). Two-level corpectomy with placement of mesh and plate, together with cervical-thoracic fixation with facet

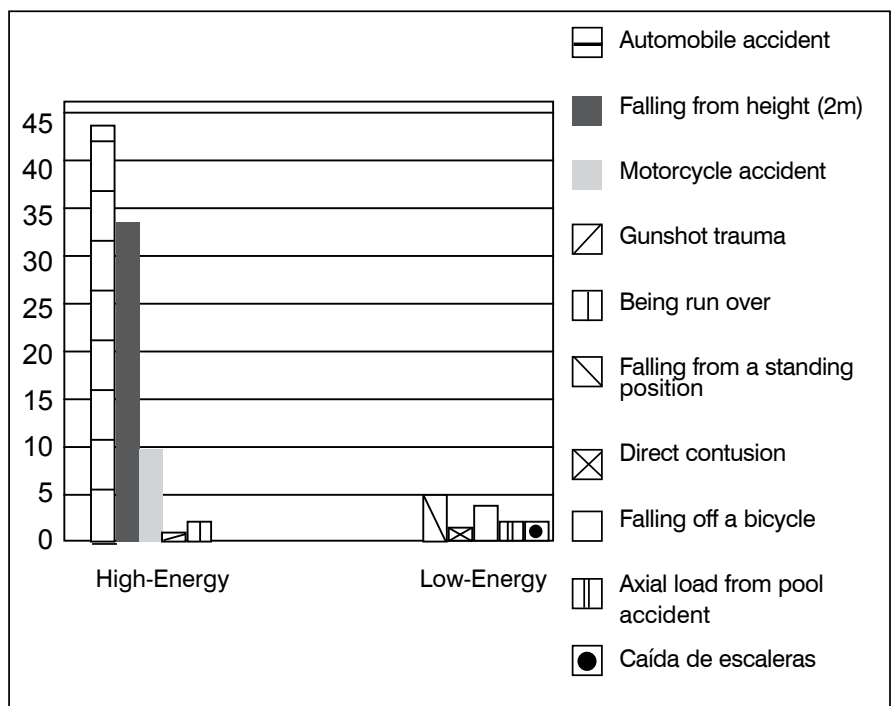

Figure 1. Mechanism of injury in cervical fractures. and pedicle screws, was performed in 3.6\% (4); the combined anterior and posterior route, performed in the same surgical intervention, with discectomy with placement of interbody mesh and plate, were performed in 1.8\% (2). Finally, posterior fixation techniques $\mathrm{C} 1-\mathrm{C} 2$ and occipitocervical fixation were performed in $0.9 \%$ (1 patient each).

Table 1. Description of the cervical segments fractured.

\begin{tabular}{c|c|c}
\hline Segment affected & Percentage & No. of patients \\
\hline C5-C6 & $24.32 \%$ & 27 \\
\hline C6-C7 & $17.1 \%$ & 19 \\
\hline C6 & $9.9 \%$ & 11 \\
\hline C4-C5 & $8.1 \%$ & 9 \\
\hline C2 & $8.1 \%$ & 9 \\
\hline C5 & $7.2 \%$ & 8 \\
\hline C3-C4 & $6.3 \%$ & 7 \\
\hline C7-T1 & $4.9 \%$ & 5 \\
\hline C7 & $4.0 \%$ & 4 \\
\hline C1-C2 & $2.7 \%$ & 3 \\
\hline C1 & $2.7 \%$ & 3 \\
\hline C2-C4 & $1.8 \%$ & 2 \\
\hline C4 & $1.8 \%$ & 2 \\
\hline C1-C3 & $0.9 \%$ & 1 \\
\hline C4-C7 & $0.9 \%$ & 1 \\
\hline
\end{tabular}

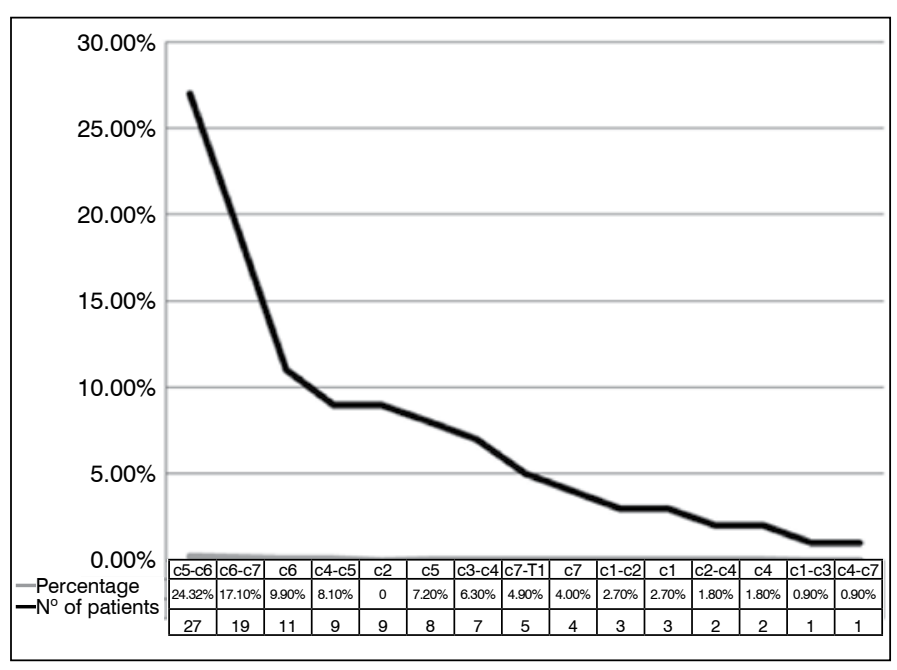

Figure 2. Description of the cervical segments fractured.

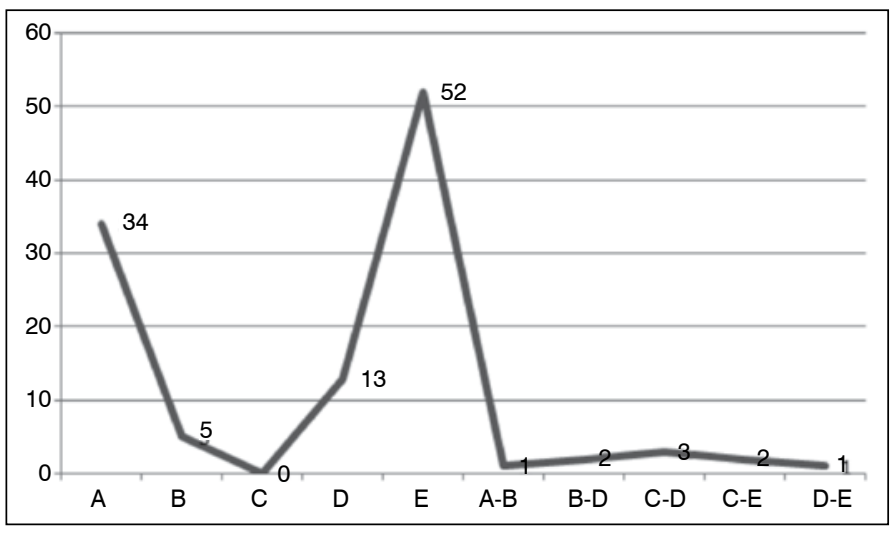

Figure 3. Neurological impairment according to the Frankel classification. 


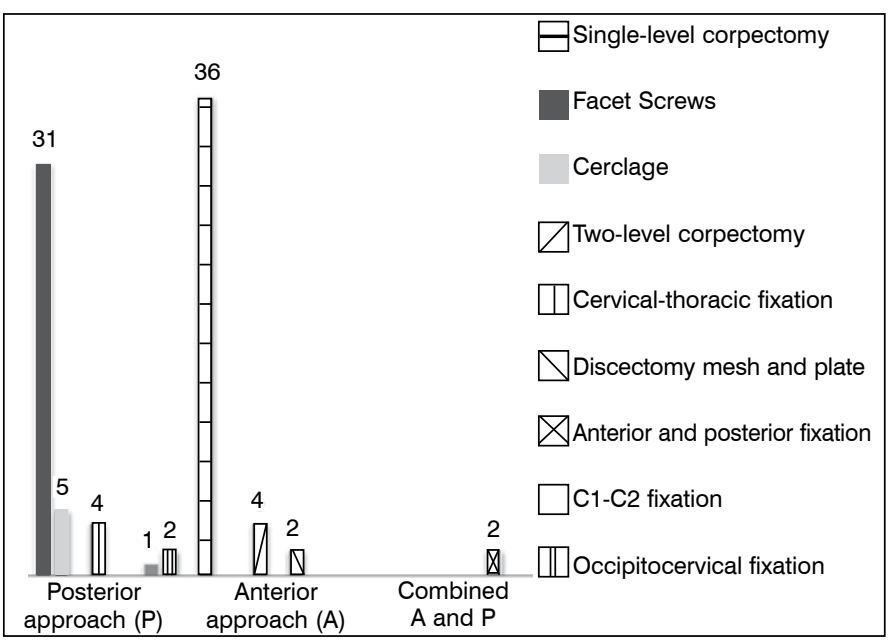

Figure 4. Surgical treatment.

\section{DISCUSSION}

In the epidemiological description by age, we found that 97 patients (87.4\% of the total sample of 111 patients) were aged between 16 and 60 years, which corresponds to the economically active population. This has important repercussions, since of this percentage of patients with cervical fractures, almost half presented some degree of neurological impairment, i.e. 52 patients, or $46.9 \%$. This is a higher percentage than the study sample of Fredo et al., ${ }^{2}$ with $10 \%$ of 319 patients, or that of Yang et al., ${ }^{6}$ with $29.2 \%$ of 106 patients. In terms of neurological recovery based on the Frankel scale, only $7 / 52$ patients $(6.2 \%)$ recovered at least one degree on the Frankel scale.

Male gender and high-energy trauma mechanisms were prevalent. (Figure 3) We therefore believe that automobile accidents, falls from heights, and motorcycle accidents should be a focus of the national prevention policies, since similar trends are observed in developing countries; this differs from the first world countries, like Norway, where automobile accidents make up $21 \%{ }^{2}$ of the total compared with $48.6 \%$ in our study (54 patients). This could be explained by the fact that the population, here in Mexico, is younger than that of European countries, where falling from standing height is the most common trauma mechanism. ${ }^{7}$
In terms of the spine segments affected, injuries of the subaxial cervical spine (C3 to $\mathrm{C} 7$ ) were more common than injuries of C1-C2, with $85.5 \%$ (95 patients) vs. 14.5\% (16 patients). Within the subaxial segment, C5-C6 and C6-C7 were the segments most affected, which were treated by a posterior approach with facet screw fixation in 31 patients (28\%), and single-level corpectomy in 36 patients (32.4\%). These are procedures that require a specific knowledge of spine surgery, and are performed in the morning, by trained surgeons. Meanwhile, we observed 5 patients (4.5\%) in whom a posterior approach with placement of a tension band (cerclage) was performed; these patients were operated on by doctors of the night shifts and the weekend shifts on Saturdays and Sundays, due to the specific need for urgent treatment, which was performed using the material available. This leads us to believe that this treatment was given to these patients in an emergency situation, knowing that the tension band with wire technique is not the most stable method in biomechanical studies. ${ }^{8}$

A tendency towards surgery is observed in the treatment delivered, given that the hospital is a tertiary healthcare institution, with 87 patients (74.8\%) who received surgical treatment being described. This case study establishes the need to meticulously characterize the population that we receive, since no reliable information is currently gathered on the trauma pathology of the spine, as described by Lee et al., ${ }^{9}$ with various Latin American countries having little reliable information.

\section{CONCLUSIONS}

Males are more affected than females; the highest percentage of cervical fractures occur in the economically active population; there is neurological impairment in around $50 \%$ of cases; the levels mostly affected are $\mathrm{C5}-\mathrm{C} 6$ and $\mathrm{C} 6-\mathrm{C} 7$; surgical treatment is the intervention most commonly used.

\section{ACKNOWLEDGMENTS}

We thank the personnel of the Medical Specialty Unit of Hospital de Traumatología y Ortopedia Lomas Verdes for enabling us to carry out this case study.

All authors declare no potential conflicts of interest concerning this article.

AUTHORS' CONTRIBUTION: Each author made significant individual contributions to the preparation of the manuscript. HVS was author. EVE collected the data. LML review the data.

\section{REFERENCES}

1. Hu R, Mustard CA, Burns C. Epidemiology of incident spinal fracture in a complete population. Spine (Phila Pa 1976). 1996;21(4):492-9.

2. Fredø HL, Rizvi SA, Lied B, Rønning P, Helseth E. The epidemiology of traumatic cervical spine fractures: a prospective population study from Norway. Scand J Trauma Resusc Emerg Med. 2012;20:85.

3. Pickett GE, Campos-Benitez M, Keller JL, Duggal N. Epidemiology of traumatic spinal cord injury in Canada. Spine (Phila Pa 1976). 2006;31(7):799-805.

4. Bracken MB, Freeman DH Jr, Hellenbrand K. Incidence of acute traumatic hospitalized spinal cord injury in the United States, 1970-1977. Am J Epidemiol. 1981;113(6):615-22.

5. Lasfargues JE, Custis D, Morrone F, Carswell J, Nguyen T. A model for estimating spinal cord injury prevalence in the United States. Paraplegia. 1995:33(2):62-8.

6. Yang S, Ding W, Yang D, Gu T, Zhang F, Zhang D, et al. Epidemiology and risk factors of cervical spine injury during heating season in the patients with cervical trauma: a cross-sectional study. PLoS One. 2013;8(11):e78358.

7. United Nations, Department of Economic and Social Affairs Population Division. World population ageing 2009. New York: United Nations; 2009.

8. Liu JK, Das K. Posterior fusion of the subaxial cervical spine: indications and techniques. Neurosurg Focus. 2001;10(4):E7.

9. Lee BB, Cripps RA, Fitzharris M, Wing PC. The global map for traumatic spinal cord injury epidemiology: update 2011, global incidence rate. Spinal Cord. 2014;52(2):110-6. 